\title{
The Need for Science and Technology Driving Forces in Sustainable Socio-economic Development of Nigeria
}

\author{
Olukayode O Adebile \\ Federal Polytechnic, Ede, Osun State, Nigeria \\ E-mail: oaadebile@yahoo.com, \\ Dahud K Shangodoyin \\ University of Botswana, Botswana \\ E-mail: shangodoyink@mopipi.ub.bw
}

Received: April 14, 2011

Accepted: July 11, 2011

doi:10.5539/jsd.v4n4p152

\begin{abstract}
This paper examines the problems confronting Nigeria as a nation and the contributions of science and technology to the economy. We observe that effective science and technology policies are crucial in advancing Nigeria economically, socially and politically given the varieties of challenges facing the largest populated nation in Africa. Alternate sources of energy to alleviate the inadequacy of electricity supply in Nigeria are suggested base on availability of needed local resources. Unemployment should be reduced through provision of soft credit loans to small scale investments and informal sectors of the economy. There should be an appreciable investment in the non-oil and agricultural sector to boost the economy. The commitment to sustainable monetary and fiscal policies and human capital development are identified as key driving factors of the Nigerian economy.
\end{abstract}

Keywords: Energy, Driving factors, Human development, Science and technology

\section{Introduction}

The 46th ministerial conference of the defunct organization of African Unity (OAU) had passed the bill that the 30th of June each year should be observe as Africans' Science and Technology day to commemorate the many achievements of science and technology and to reflect on challenges such as the missed cues, the missed inventions, the lack of supporting environments for science and technology to thrive and our general lack of interest in science and technology (S\&T). Although Africa is truly in the age of science with many breakthroughs the S\&T day is likely to pass without any one making a note of it because it seems that Africans have surrendered to the rest of the world in science and technology. In Nigeria for instance, a basic assumption would be that many literates know or in the least are expected to know that globalization is driven by science and technology. This assertion is due to wide acceptance of Internet technology (IT) and this has facilitated rapid opening up and integration of national economies. IT is the engine of economic liberalization and associated developments in international trade. According to Ogbu (2004), Nigerians as consumers of science and technology are fascinated by gadgets especially the latest ones, their speeds and designs/brands are appreciated.

Science and technology are central to the developmental prospects of poor countries. They can provide tools that help alleviate the specific problems that afflict many poor countries and which impede their development prospects, such as disease, infrastructural (energy, communication, transport, etc.) decay, and the degradation of the environment. S\&T are also central to the dynamics of economic development itself. Economically successful countries are those that are able to turn technical innovation into economic productivity. Effective science and technology policies are thus crucial for the developing countries. The success stories of Japan, Korea, and Taiwan, for example are in large part stories of a long-term strategic policy focused on fostering indigenous innovation capacity.

Specifically, this paper addresses the importance of science and technology development in Nigerian economy. It discusses Nigeria challenges as sovereign nation and the role of science and technology in the face of current global competitiveness.

\section{Essentials of Science and Technology}

The word science comes from the Latin "scientia," meaning knowledge. According to Webster's New Collegiate Dictionary (1977), science is "knowledge attained through study or practice," or "knowledge covering general truths about the operation of general laws, especially as obtained and tested through scientific method and concerned with the physical world."

According to Wikipedia the free online encyclopaedia, the word technology comes from the Greek technología, téchne means 'craft' and logia is the study of something or the branch of knowledge of a discipline. It is the usage and knowledge of tools, techniques, and crafts or it is systems or methods of organization or a material product 
(such as clothing) of these things. The term can either be applied generally or to specific areas, examples include "construction technology", "medical technology", or "state-of-the-art technology".

Technologies significantly affect human as well as other animal species' ability to control and adapt to their natural environments. The human species' use of technology began with the conversion of natural resources into simple tools. The pre-historical discovery of the ability to control fire increased the available sources of food and the invention of the wheel helped humans in travelling in and controlling their environment. Recent technological developments including the printing press, the telephone, the computer and the Internet have lessened physical barriers to communication and allowed humans to interact freely on a global scale.

Esho (2008) emphasizes that no advantage is permanent competitors are creating new values to attract greater ones. We have a competitive environment in Nigeria and it is evident that nobody would develop our economy for charity. The strength of a nation is gauged and evaluated on the basis of contemporary issues and challenges left unresolved. The achievements of a nation is a measure of the commitment to technical education in terms of her technological contribution to global economy and how national needs are matched with technical education curricula and proper planning. Compton (2004) mentioned that due to the nature of contemporary society, the relationship between the domains of science and technology has never been stronger.

Science and technology have different purposes and ways of viewing and knowing the world thus their relationship is often tense and complex. However, they serve to inform and extend each other in both intended and unexpected ways. Scientific knowledge and methodologies themselves provide a major source of input into the development of technological practices and outcomes. They are also key tools in the establishment of explanations of why technological interventions were, or were not, successful.

Technological practices, knowledge and outcomes can provide mechanisms for science to gain a better view of its defined world, and in fact can provide serious challenges to the defining of that world. For example, the development of the technological artifacts that extend the observation capabilities of humans (such as the telescope and microscope), made 'visible' and available 'new worlds' for science to interrogate and explain.

\section{Issues and Challenges Confronting Nigeria as a Sovereign Nation}

Nigeria has been exceptionally favored and blessed with abundant natural, mineral and human resources. A nation that is totally devoid of natural calamities or disaster cannot be said to be less favored but the only natural disaster is bad leadership. Nigeria's political problems (corruption-civil or social), lawlessness and deceit in high places have led her into several contradictions and change of policies. The failure of our leaders to raise the standard of living of the average Nigerians beyond poverty line coupled with unemployment, has dampened the morale of most Nigerians with respect to the possibility of finding an effective solution to the various challenges confronting us as a nation.

Ogbu (2004) says that Africa's brain drain phenomenon has both pull and push factors that have contributed significantly to the poor state of S\&T in the region. Given poor political and economic conditions of most African states, many top scientists left the shores of Nigeria and refused to return because some developed countries also put in place policies to attract highly specialized Africans thereby depleting the meager stock.

The objectives of the Nigeria 1981 National Policy on Education is to train manpower in Engineering, Applied Science, Technology and Commerce at all professional grades, and the provision of technical knowledge and vocational skills necessary for agricultural, industrial, commercial and economic development. These objectives have become mere theories and have remained on the pages of papers. A review of Nigerian Polytechnic systems reveals that Polytechnic education is underrated, discriminated against, disowned, neglected, denigrated, snubbed and ignored.

The standard of education is falling and the consequence is the production of half-backed graduates and job seekers who incidentally roam the streets looking for white collar jobs. The rates of social vices (bank robbery, kidnappings, arms struggle, cultism, ritual killings, drug peddling, religious conflicts etc) have increased in the country. Ibiyemi (2007) stressed that Nigerian educational system has been disorganized. He feels that university education is not for everybody, though everybody should be given a chance to prove their ability.

Nigeria is politically an unstable country. The country has being bedeviled by all sort of negative forces: the North is campaigning for the enactment of Sharia law, in the south-east the Movement for the Actualization of the Sovereign State of Biafra (MASSOB) holds sway, in the south-west, the Oodua People's Congress had been championing a violent form of ethnic nationalism. In the creeks of the Niger Delta, the youths are in a virtual state of rebellion. There is inadequate business infrastructure, power supply is erratic, and there is no source of drinkable water. The communication facilities have broken down. There is fuel scarcity, inefficient civil service, inadequate crime control and poor judicial system.

There is no doubt that human capital is the most important form of wealth for a modern nation. According to Iredale (2003), countries with the most intellectual resources achieve the highest rates of economic growth and the fastest development in S\&T. Knowledge produces economic riches and also is a vital ingredient for dealing with many of the social and environmental problems of our lives today. In the drive for human capital, many 
industrialized countries (United States, the United Kingdom, Canada, Germany, Japan, Singapore, Hong Kong and Australia), give priority to policies aimed at attracting highly skilled immigrants.

To Dike (2005), the issue of the upsurge of corruption in Nigeria is troubling and the damages it has done to the polity are astronomical. The menace of corruption leads to slow movement of files in offices, police extortion at tollgates and slow traffics on the highways, port congestion, queues at passport offices and gas stations, ghost workers syndrome, election irregularities, among others.

Policy continuity is also lacking in Nigeria, according to Akuta (2009) once a new government takes over power, it usually abandons previous governmental policies or programs. Very few policies have been retained by subsequent administrations (both military and civilians). The National Youth Corp Scheme (NYSC) has lasted over 36 years. The federal character principle (inserted in the 1979 constitution) has lasted since 32 years. High level official corruption, which though is not legislated, has become part of most governments since over 50 years of our existence as a nation. These policy inconsistencies are an avenue for siphoning public funds. Every government policy, program or project cancelled means loss of government revenue, it brings with it destabilization and sets the people and the nation backwards especially when people have invested money, time and other resources.

DSC (2007) observes that Nigeria is an example of a mostly rural developing country whose government is unable to provide some basic services, such as potable piped water and electric power to a large proportion of the population in an affordable manner. In other developing countries, many of these services are available from private, profit-making companies using readily accessible technologies. Nigeria receives a large income from oil production and the export of natural gas to neighboring countries in West Africa. The lack of energy service has a significant impact on nearly all of the country's development goals. In urban areas, which are mostly served by the grid, frequent power breaks affect the viability of existing industries and the development of new ones. Expensive private generators are frequently the only recourse. Small businesses and homes in poor neighborhoods are often bypassed by the grid, and power theft is a common problem.

In almost everywhere in the country, unlit homes and communities prevent children from completing their homework at night and thus have a negative impact on education. Research works are often abandoned due to erratic power supply or even outright withdrawal.

\subsection{Current Status of the Nigerian Nation}

The annual inflation rate averaged $19.65 \%$ between the period 1980 and 1990 with a maximum rate of about $45 \%$ see Table 1. Between 1990 and 2000, the mean rate was about $28.70 \%$ with a maximum of about $76.80 \%$. It is evident from this analysis that the standard of living of the people was bad within this period. In this same table, we observe that the inflation rate came down to an average of $12.41 \%$ and a maximum of $23.80 \%$ during the period 2000 and 2010. The inflation rate dropped between 2005 and $2007(11.565 \%$ to $6.577 \%)$ and rose sharply to 15.054 in 2008 see Figure 1.

From Table 2, we observe that between 1980 and 1990, the Gross Domestic Product per Capital (GDPPC) averaged to $\$ 463.96$ with a maximum of about $\$ 885.27$. However, GDPPC fell to an average of $\$ 305.15$ between 1990 and 2000 with a maximum of about $\$ 431.3$, as against $\$ 885.27$ of the previous period.

In Figure 2, we also observe that during the period 2000-2010 the GDPPC rose to an average of about $\$ 825.62$ with a maximum of $\$ 1401.24$. GDPPC rose from around $\$ 250$ in 2002 to about $\$ 1,153.40$ in 2007 and to $\$ 1,401.24$ in 2008 bur dropped to $\$ 1,089.30$ in 2009 .

\subsection{Nigeria Compared with other Nations}

From the CIA World Fact book 2009, the followings facts were obtained. The rate of growth of Nigeria's population was $12 \%$ per annum placing us as the 60th worst countries in the world. The life expectancy (LEB) of people in Nigeria by 2009 statistic was 46.94 years placing us in the 209th position with Japan having 82.12 years LEB. Nigeria was ranked 8th in population density with a population of $149,229,090$ people. The percentage of people below poverty line was $70 \%$ placing us in the 9th worst country in the world while Taiwan has less than $1 \%$.

The industrial production rate of Nigeria was $2.8 \%$ placing us in the 87 th position as against China $(9.3 \%)$ in the 15 th position. Electricity production by Nigeria was $22.11 \mathrm{bKwh}$ placing us in the 68th position with the United States $(4,167 \mathrm{bKwh})$ in the 1st position. South Africa with one third of the population of Nigeria had $264 \mathrm{bKwh}$ of electricity production. Oil production was 2,440,000 barrels per day placing us at the 12th oil producing country in the world although fuel was still imported to power the economy. Nigeria's gas production was put at $21,480,000,000$ cubic meters placing us as the 26th producer in the world although gas was out of reach of the poor.

The inflation rate of $11.6 \%$ in the period $2000-2010$ placed the country in the 56th worst position. The growth rate in GDP of 5.3\% placed the country in the 76th position. The GDPPC of $\$ 2,100$ also placed us in the 175th place. Nigeria's current account balance was $\$ 14,610,000,000$ and foreign reserves of $\$ 50,330,000,000$ placed us in the 20th and 26th positions respectively. Nigeria's total export value in 2009 was $\$ 76.8 \mathrm{~b}$ which placed us in 
the 42nd position.

According to the Daily Trust of November 26, 2008 in Dike (2009) the federal government acknowledged that about 80 per cent of Nigeria's youths are unemployed and 10 per cent underemployed.

Akwenuke (2008), quoting the then Minister of State for Foreign Affairs as saying that the federal government would require 600 billion dollars in foreign investment to make Nigeria one of the top 20 economies in the world by 2020 . With all these it is unlikely that the anticipation of the Nigerian government to place Nigeria in the $20^{\text {th }}$ position by the year 2020 could be met.

Victor (2009) opined that while vocational and technical education has continued to thrive in many societies, Nigeria has neglected this aspect of education. Consequently, the society lacks skilled technicians to run the economy.

\section{Confronting National Problems through S\&T}

From the issues confronting Nigeria discussed above, Ekpiwhre (2008) asserts that it is important for us to appreciate the potency of S\&T to bring about significant changes in our local, state and national lives. Investments in S\&T always pay off, sometimes immediately but always in the long run.

Countries like the United Kingdom and France benefited immensely from the industrial revolution of the 19th Century, and the United States emerged from an agrarian economy into an industrial superpower in the 20th century, through effective application of S\&T.

In fact, these countries invested quite heavily in people and factories, and their successes were based on carefully designed plans and strategies. Unfortunately, virtually all the available statistics show that while the rest of the world has advanced technologically, Africa has fallen relatively further behind.

The discoveries in science and technology have greatly led to tremendous success in the manipulation of material resources and human environments in favor of humanity. The resultant effect of scientific and technological innovations in medicine, engineering, meteorology, agriculture, management, economics, law, marine, aeronautics, in the three centuries have impacted tremendously on every aspect of human endeavor. A World Bank report indicated that the first industrial revolution in the United Kingdom took 58 years i.e. 1780 1838, while the adoption of improved technology took other countries less to attain the same feat. For instance in USA, it took just 46 years i.e. 1839 - 1885, Japan 34 years, South Korea 11 years, China 10 years, etc. This means that if we are committed to national development, we may still breakthrough technologically by 60th year of our independence.

\subsection{Eradicating Poverty through Credit Facilities}

To revitalize the country, poverty must first be reduced to the barest minimum. Yunus (1998) established the Grameen Bank of Bangladesh, where he had created innovative entrepreneurial programs to benefit the rural poor. More than 2.3 million Bangladeshis, spread over 37,000 villages, have borrowed from Grameen Bank. Cumulatively, the bank, a financially sustainable, profit-making venture with 12,000 employees, has loaned \$2 billion, and virtually every cent has been repaid. It is not a charity, not a program based on good will or political favors. It does not subsidize the poor, they are its borrowers and its shareholders. The bank makes small loans that average about $\$ 60$ each, thereby providing microcredit as an effective tool. Apart from Bangladesh, there are Grameen programs replicated in 58 different countries on 4 continents. In all there are 241 international programs in countries as diverse as Nigeria, Tanzania, Kenya, China, Nepal, Indonesia, Sri Lanka, Papua New Guinea, France, Norway, Jamaica, Mexico, Colombia, Canada, and the United States. Thus, there is the potential to empower the poor to attain sustenance through credit and self-employment in nearly all parts of the globe, and to link this global network of microcredit borrowers, the Internet has been an effective tool.

A major benefit of this Internet service is that borrowers can link themselves and even their banks at easy. Internet services and associated activities like telephone calls and selling of handsets and accessories can easily be undertaken by the youths for self-employment.

\subsection{Alternative Energy To Power Nigeria Economy}

Alternative energy sources are renewable and are thought to be "free" energy sources. They all have lower carbon emissions, compared to conventional energy sources. These include Biomass Energy (Biomass is biological material derived from living, or recently living organisms. In the context of biomass for energy this is often used to mean plant based material, but biomass can equally apply to both animal and vegetable derived material), Wind Energy, Solar Energy, Geothermal Energy (Geothermal energy is the heat from the Earth. It's clean and sustainable. Geothermal heat pumps can be used to heat and cool buildings).

\subsubsection{Biomass: Energy from Garbage}

In Science Daily (2009) some scientists in Singapore and Switzerland claim that converting the rubbish that fills the world's landfills into biofuel may be the answer to both the growing energy crisis and to tackling carbon emissions. New research published in Global Change Biology: Bioenergy, reveals that replacing gasoline with biofuel from processed waste could cut global carbon emissions by $80 \%$. Their study suggest that fuel from 
processed waste biomass, such as paper and cardboard, is a promising clean energy solution said study author Hugh Tan of the National University of Singapore. If developed fully, biofuel could simultaneously meet part of the world's energy needs and also combat carbon emissions and fossil fuel dependency. The team found that 82.93 billion liters of cellulosic ethanol could be produced from the world's landfill waste and that by substituting gasoline with the resulting biofuel, global carbon emissions could be cut by figures ranging from $29.2 \%$ to $86.1 \%$ for every unit of energy produced.

From Garbage Electricity CHAMCO USA, city wastes, which are costly to dispose, are handled in the most environmental friendly manner on the site to generate electricity and produce fertilizer and construction material. This unit uses Municipal Solid Waste (MSW), even garbage with as low as $800 \mathrm{Kcal} / \mathrm{Kg}$ and moisture content of up to $50 \%$. The raw garbage is turned into RDF (Refused Derived Fuel) pellet. The pellets together with $30 \%$ auxiliary fuels such as: gas, coal, rice husk, etc., using specially designed boiler, produces heat for steam turbine to run electric generator. In Nigeria there are several garbage dump sites all over (see Figure 3) these could serve as source to produce Biomass energy with cheap S\&T technology in Nigeria.

\subsubsection{Energy from Wind Power}

Wind power is another rapidly developing alternative to fossil fuel. Societies have taken advantage of wind power for thousands of years. The first known use was in $5000 \mathrm{BC}$ when people used sails to navigate the Nile River. Persians had already been using windmills for 400 years by $900 \mathrm{AD}$ in order to pump water and grind grain. Windmills may have even been developed in China before $1 \mathrm{AD}$, but the earliest written documentation comes from 1219. Cretans were using "literally hundreds of sail-rotor windmills to pump water for crops and livestock." Today, people are realizing that wind power "is one of the most promising new energy sources" that can serve as an alternative to fossil fuel-generated electricity. As of 1999, global wind energy capacity topped 10,000 megawatts, which is approximately 16 billion kilowatt-hours of electricity. That's enough to serve over 5 cities the size of Miami, according to the American Wind Energy Association. Germany, the US, Spain, Denmark, and India are among the world's leading nations in the acquisition of wind energy. Interestingly, the instruments are simple S\&T devices that could be adopted in Nigeria, see Figure 4.

\subsubsection{Bituminous Sand}

Petters (2011) says that about 31 billion barrels of heavy crude oil is held in bituminous sand deposits in south-western Nigeria. The bituminous sand deposits occur in $12 \mathrm{~km}$ - wide belt that extends from ljebu-Ode in Ogun State, through Ondo State, to Edo State. Nigeria imports an average of 50,000 barrels of heavy crude oil a day from Venezuela for producing "base oil" which is used to blend with lubricants and greases in Kaduna Refinery. There is, therefore, a need to extract heavy oil from the Ondo deposit for the refinery and for bitumen.

\subsubsection{Solar Energy}

Petters op cit is of the opinion that as Nigeria is situated approximately between $4^{\circ} \mathrm{N}$ and $13^{\circ} \mathrm{N}$, she is geographically favorably located to tap unlimited solar energy, the most dependable renewable energy source. It has been estimated that a yearly average of about $2,300 \mathrm{kwh} / \mathrm{m}^{2}$ of solar energy tails on a horizontal surface in Nigeria. In Lagos, the intensity of solar radiation is about $930 \mathrm{w} / \mathrm{m}^{2}$ on a clear sunny day. What Nigeria requires is an affordable solar energy technology and cheap appliances.

\subsubsection{Nuclear Energy}

$\mathrm{He}$ also is of the opinion that nuclear power is one of the most feasible alternatives to fossil fuels in the developed countries. However, its prospect in Nigeria is as yet a curiosity. So far, uranium traces have been found near Gombe in Gombe State and Ugep in Cross River State. In Sokoto and Ogun states, radioactive phosphate grains occur. However, given the widespread peaceful applications of nuclear technology in agriculture and animal production, medicine, mineral exploration and environmental protection, Nigeria should be keenly interested in nuclear science and technology.

\section{Conclusions and Recommendations}

Economically successful countries are those that are able to turn technical innovation into economic productivity. Effective S\&T policies are thus crucial for developing countries. Nigeria as a nation must appreciate the potency of S\&T to bring about significant changes in our local, state and national lives. Private individuals in Nigeria could be encouraged to do like Yunus of Bangladesh given the conducive environment.

Entrepreneurial centre should be setup to train and retrain young graduates to pick up one vocation or the other especially in the energy sector. Loans should be made available for establishment of small scale industries by these young Nigerians.

Government should fund research in S\&T and attach grants to breakthroughs. Government should invest in the non- oil and agricultural sector of the economy to absorb research outcomes. The Nigerian government can turn to the very active private sector to provide these basic products and services.

Government should redesign and implement effective monetary and fiscal policies in line with current trend in S\&T. Incentives should be provided to individuals and organizations to invest in the economy, and encourage proper competition to increase the quantity and quality of goods and services. 
We need to manage our waste (waste to wealth) the garbage on our roads can be converted into electricity. Wind power is another rapidly developing alternative to fossil fuel. Government should explore possibilities in this direction. Other alternative sources like solar and nuclear energy could be used to solve the energy crises in the country.

This will give room to rapid industrialization and a dynamic service sector to create jobs to reduce the rising youth unemployment and underemployment in the society.

Government must provide the enabling environment like good road, security of lives and property, good remuneration and zero tolerance to corruption. When corruption is eliminated, honesty and hard work will follow. The citizens will obey the law and order. Otherwise we shall continue to invite the super powers to mend our roads, build our houses, provide relieve materials and dictate our economy and our politics.

\section{References}

Akuta, C. V. (2009). Inconsistent Policies and High Rate of Abandoned Government Projects', "Support Option A4 Group", Leicester-UK. Available: http://briefsfromakuta.blogspot.com/

Akwenuke, B. (2008). Vision 2020: Nigeria Needs \$600bn Investment. [Online] Available: http://rsagroup.net /indogeria/2008/05/06/vision-2020-nigeria-needs-600bn-investment/

American Wind Energy Association. http://www.altenergy.org/renewables/

CHAMCO, USA. Garbage Electricity: Municipal Solid Waste Conversion to Energy. [Online] Available: http://www.chamco.net/garbage_electricity.html

Compton, V. (2004). The Relationship between Science and Technology, a Discussion Document prepared for the New Zealand Ministry of Education Curriculum Project. Available: http://www.tki.org.nzcurriculum/whats_happening/index_e.php)

Development, Security, and Cooperation (DSC) (2007). Mobilizing Science-Based Enterprises for Energy, Water, and Medicines in Nigeria. Available: www.nap.edu/openbook.php?record_id=11997\&page=1

Dike, V. E. (2005). Corruption in Nigeria: A New Paradigm for Effective Control, Africa Economic Analysis. Available: www.AfricaEconomicAnalysis.org

Dike, V. E. (2009). Addressing Youth Unemployment and Poverty in Nigeria: A Call For Action, Not Rhetoric, Journal of Sustainable Development in Africa, Vol. 11, No.3, ISSN: 1520-5509

Ekpiwhre, G. (2008). Utilising science and tech to drive Vision 2020, Punch News Paper Publications Excerpts of a speech delivered at Tinapa resort Calabar during the Diaspora Day in July.

Esho, M. A. F. (2008). A keynote address delivered at the opening ceremony of the 4th international conference of the schools of Science, Engineering and Environmental Technology, The Federal Polytechnic, Ede.

Federal Republic of Nigeria (1981). National Policy on Education, (Revised); Lagos, Nigeria NERC Press.

Ibiyemi, T. S. (2007). Rule of law and due process: A priority for sustainable development in Sciences, Engineering and Environmental Technolgy in Developing Nations' Being a lecture delivered at the 3rd international conference of NACONSEET held at Federal Polytechnic, Ede, Osun State, Nigeria.

Iredale, Robyn, Fei Guo and Santi Rozario (2003). Return Migration in the Asia Pacific. Available: www.scidev.net/ 08/12/2003.

Ogbu, O. (2004). Can Africa Develop Without Science and Technology?, The African Technology Policy Studies Network, P.O. Box 10081, 00100 General Post Office. [Online] Available: http://www.atpsnet.org

Petters, S. W. (2011). Nigeria-Geological background: [Online] Available: www.onlinenigeria.com/geology/

Science Daily (2009). Is Garbage The Solution To Tackling Climate Change? Wiley-Blackwell, Retrieved April 22, 2010. Available: http://www.sciencedaily.com-/releases/2009/09/090929100654.htm

Victor, E. D. (2009). Technical and Vocational Education: Key to Nigeria's Development. Available: www.nigeriavillagesquare.com/.../victor.../technical-and-vocational-

Webster's New Collegiate Dictionary (1977). Springfield, Mass.: G. \& C. Merriam.

Wikipedia the Free online Encyclopedia (2010). [Online] Available: www.wikipedia.org/

Yunus, M. (1998). Alleviating Poverty Through Technology, Essays on Science and Society, Vol. 282. No. 5388, pp. 409 - 410. [Online] Available: www.sciencemag.org/cgi/content/full/282/5388/409 
Table 1. Descriptive Statistics of Inflation Rate

\begin{tabular}{|l|r|r|r|}
\hline & \multicolumn{3}{|c|}{ Inflation Rate Annual \% Change } \\
\hline & \multicolumn{3}{|c|}{ Sample Period } \\
\hline Statistic & 19811990 & 19902000 & 20002010 \\
\hline Mean & 19.6495 & 28.66336 & 12.40509 \\
\hline Median & 15.448 & 14.525 & 11.565 \\
\hline Maximum & 1.066 & 76.759 & 23.811 \\
\hline Minimum & 15.99795 & 0.225 & 6.577 \\
\hline Std. Dev. & 0.440255 & 0.636477 & 1.090395 \\
\hline Skewness & 1.698972 & 1.948444 & 3.656949 \\
\hline Kurtosis & 1.028322 & 1.2495 & 2.377569 \\
\hline Jarque-Bera & 0.598002 & 0.535395 & 0.304591 \\
\hline Probability & & & 2690912 \\
\hline
\end{tabular}

Source: Authors' calculations using IMF World Economic Outlook Database, 2009

Table 2. Descriptive Statistics of GDP Per Capital

\begin{tabular}{|l|r|r|r|}
\hline & \multicolumn{4}{|c|}{ GDP Per Capital US Dollars } \\
\hline & \multicolumn{3}{|c|}{ Sample Period } \\
\hline Statistic & 19801990 & 19902000 & 20002010 \\
\hline Mean & 463.956 & 305.1509 & 825.6215 \\
\hline Median & 347 & 310.475 & 823.824 \\
\hline Maximum & 885.273 & 431.264 & 1401.24 \\
\hline Minimum & 254.845 & 160.529 & 358.732 \\
\hline Std. Dev. & 251.9718 & 81.23144 & 367.5437 \\
\hline Skewness & 0.890611 & -0.452279 & 0.075618 \\
\hline Kurtosis & 2.075692 & 2.533976 & 1.549744 \\
\hline Jarque-Bera & 1.845753 & 0.474561 & 0.974469 \\
\hline Probability & 0.397374 & 0.78877 & 0.614323 \\
\hline
\end{tabular}

Source: Authors' calculations using IMF World Economic Outlook Database 2009

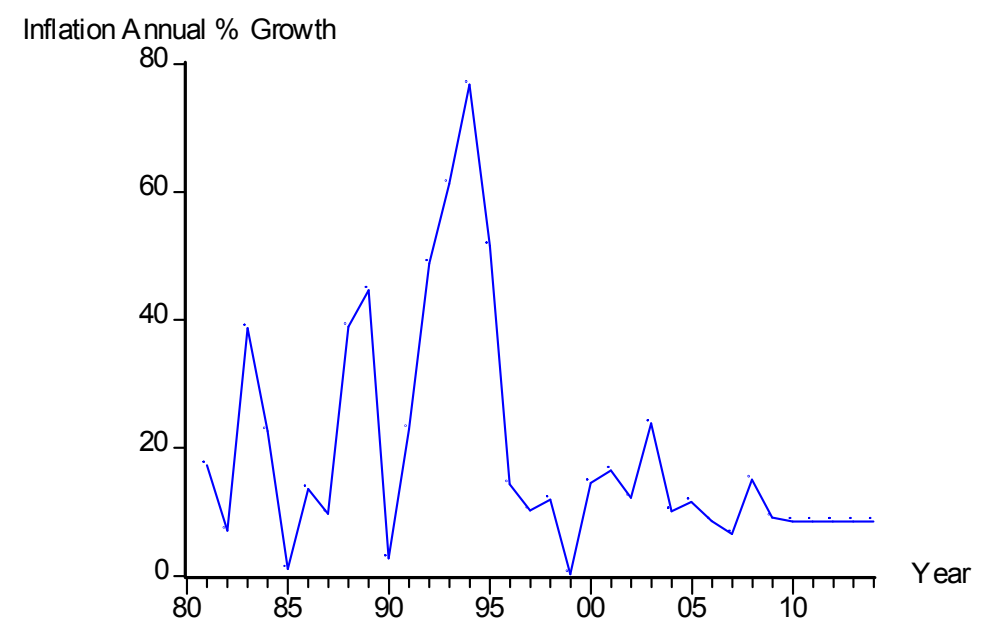

Figure 1. Plot of Inflation Rate over Time 


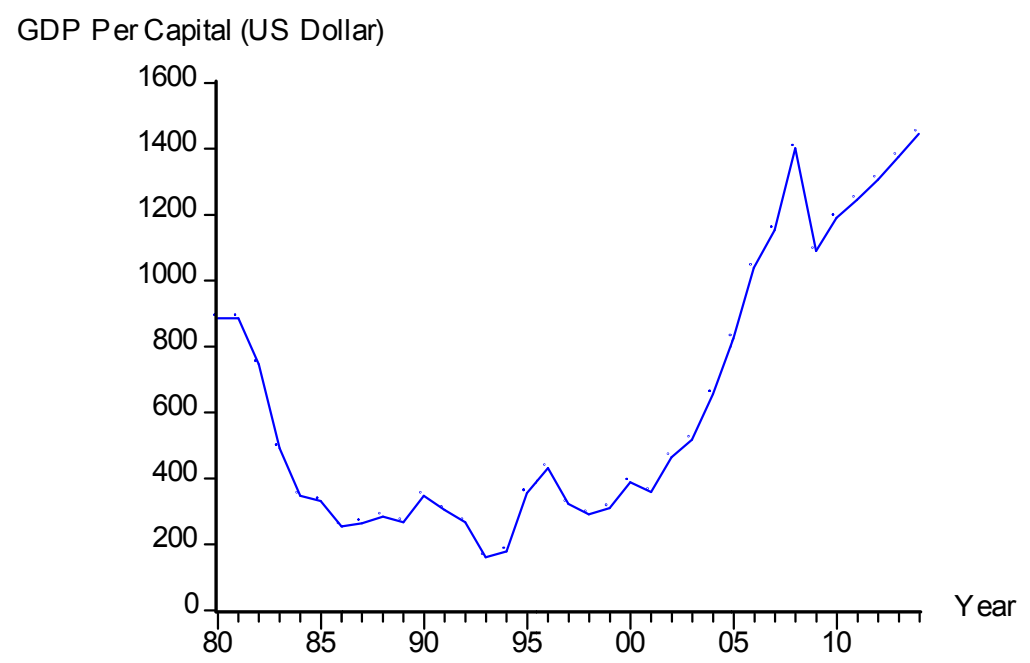

Figure 2. Plot of GDP Per Capital over the Period

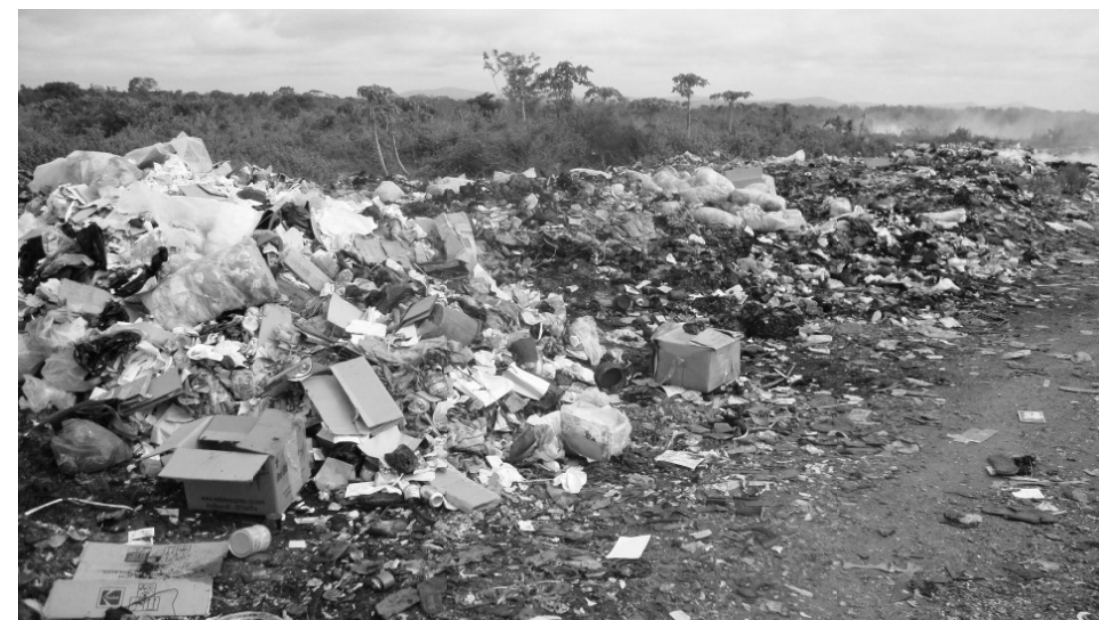

Figure 3. Garbage on a dump site Iwo-Ibadan Road, Osogbo, Nigeria. Source: Author’s Photograph

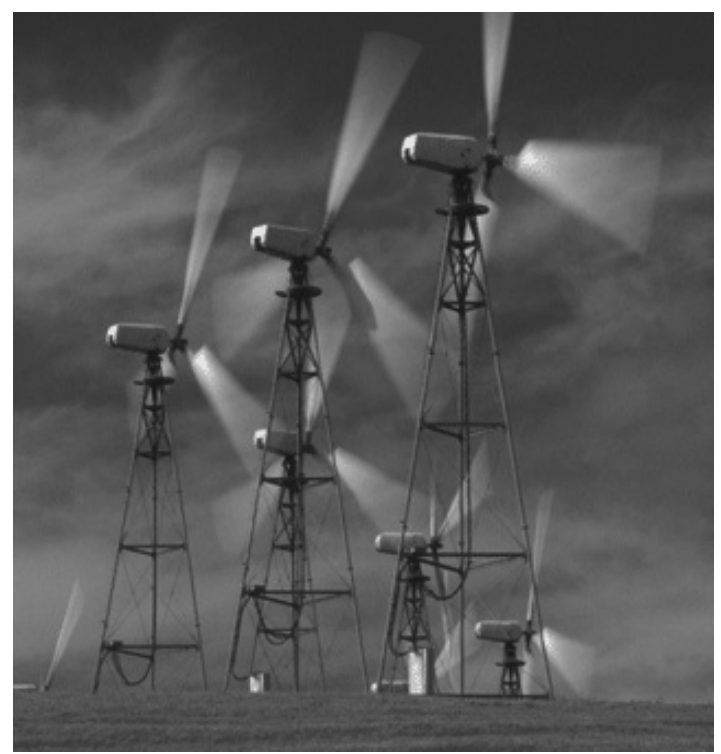

Figure 4. Wind Mills for generating Electricity 